\title{
Dynamic Spatial Model of Non-Domestic Waste Transport in Strategic Areas
}

\author{
Minnaty Syahiya ${ }^{2,3 *}$, Erri Noviar Megantara ${ }^{1}$ dan Teguh Husodo ${ }^{1}$ \\ ${ }^{1}$ Lecturer Environment Science Program, Postgraduate School, Padjadjaran University, Indonesia \\ ${ }^{2}$ Student Environment Science Program, Postgraduate School, Padjadjaran University, Indonesia \\ ${ }^{3}$ Staff Public Works Office of Human Settlements, Spatial Planning and Irrigation, South Sumatera, Indonesia
}

\begin{abstract}
The development of strategic areas that are taking place in several cities and districts in Indonesia is one of the solutions to the problem-solving approach instructed by the central government to develop the economy. However, along with the development of physical development and infrastructure in this strategic area, environmental problems began to emerge, especially solid waste. Increased community activity is one of the triggers for this increasing environmental problem. This research is a literature study that will answer the problem, what digital tools (applications / software) in a dynamic spatial model can support the final performance and what outputs can be obtained in its use. The method used is a qualitative method, research data is obtained from secondary data, several journals or articles that reveal about solid waste management. Data analysis was performed using descriptive analytical techniques. The mapping software application will simulate the determination of the location of waste collectors, visual representation of transportation routes, and optimization of transportation issues in order to provide economic and environmental benefits by reducing travel time, distance, fuel consumption, and pollutant emissions. The dynamic spatial model shows that the ArcGIS simulation results can be used as a strong basis for measuring the overall optimal route in solid waste management and dealing with dynamic changes in the future. Incorporating planning details on paper with real-world boundaries allows for realistic comparisons, for the application of sustainable environmental planning.
\end{abstract}

\section{Introduction}

The Central Government issued a National Spatial Plan 2008-2028 (RTRWN), as a reference in spatial planning with the aim of prioritizing areas requiring accelerated development. Then it is examined in more detail through the Provincial RTRW and then harmonized again with the City / Regency RTRW. This is an attempt by the government to control areas that are quite slow in development, so our economy rate can grow.

As a more detailed example, in the RTRW of South Sumatra Province, it is stated that Muara Beliti District, Muara Lakit District and Rupit District as Local Activity Centers (PKL). This indicates that there will be infrastructure development in this strategic area. Muara Beliti District, which is the capital of Musi Rawas Regency, carries out an area development program under the Public Works Office of Cipta Karya, Spatial Planning and Irrigation of Musi Rawas Regency which is contained in the PD Work Plan (Renja), "The Development of Adequate Public Facilities And Infrastructure In Agropolitan and Fast Growing Strategic Areas". Taman Beregam Square in Muara Beiti was used as the center point for the capital of Musi Rawas district, then there was an increase in development by optimizing open space with studios, parks, ponds, amphitheater, wall climbing, children's play facilities, cafes and various other supporting facilities.

As time goes on, developments are progressing and developing, which is marked by growing trading activity around the area. This development has an impact on increasing the number of visitors which in turn will increase the generation of non-domestic waste. Because this strategic area is a commercial area, waste in the area is categorized as non-domestic waste. Garbage is a problem that is closely related to environmental management. Therefore, strategic area development planning like this requires collaboration with environmental planning to achieve integration between development and the environment.

The formulation of the problem in this research is what digital tools (application/ software) in a dynamic spatial model are able to support the final results and what outputs can be obtained. The purpose of this research is to find the right digital tools for spatial transportation arrangements. As a preventive measure before the accumulation of garbage at several collection points. The benefit of research is that it can assist in choosing the right digital tools (applications/ software).

\footnotetext{
* Author: minnatysyahiya@gmail.com
} 


\section{General Information on Dynamic Spatial Model and Non-Domestic Waste Management}

\subsection{General Information on Dynamic Spatial}

According to the Big Indonesian Dictionary (KBBI), a model is a pattern (for example, references, variations, etc.) of something to be made or produced. Spatial is with regard to space or place. Space according to [4] is a physical element, but it is also air which is essentially formless. The spatial system according to [4] is an integration of three-dimensional program elements and spaces that accommodate several functions and relationships in a building. According to the Big Indonesian Dictionary (KBBI), dynamic is something that contains dynamics. Dynamics itself means moving. So that the Dynamic Spatial Model is a dynamic spatial planning reference pattern or it can be adjusted and developed from time to time.General Information on Dynamic Spatial.

The use of Geographical Information Systems (GIS) is an approach through mapping to analyze complex spatial phenomena. GIS is able to create, process and present data in order to produce quality, accurate and relevant mapping information. The following are some commonly used GIS applications / software:

- ArcGIS;

- Android based mapping with GPS; dan other application

\subsection{General Information on Non-Domestic Waste Management}

Waste based on its source can be grouped into domestic waste and non-domestic waste. Domestic waste is waste generated from household activities or environment while non-domestic waste is waste originating from commercial waste, industrial waste, institutional waste, building waste, municipal service waste, processing plant sludge and other residues, and agricultural waste.

According to RI Law no. 18 of 2008 concerning Waste Management, waste is the remains of human daily activities and/ or natural processes in solid form. Waste management is a systematic, comprehensive and continuous activity which includes waste reduction and handling. Waste based on the source of waste:

1. Households, generally consisting of organic and inorganic waste, which are generated from household activities. For example, from kitchen waste, gardens, dust, and household appliances

2. Commercial areas, waste generated from shops, restaurants, markets, offices, hotels, etc

3. Institutional waste, originating from schools, hospitals and government centers

4. Industrial waste, originating from industrial production processes, from processing raw materials to production results

5. Garbage from public facilities, originating from public parks, beaches or recreational areas
6. Waste from the remains of building construction, waste originating from the remains of building construction, repairs, demolition of roads, bridges, etc.

7. Waste from waste water management and waste from the incenerator

8. Agricultural waste comes from agricultural scraps that can no longer be used [3]

The implementation of waste management includes several phases of implementation, and the final disposal phase consists of several methods:

1. The supply phase or the shelter phase

2. The collection and transportation phase

3. The disposal phase

\section{Methodology}

Data obtained for this research process has two sources, the first is documents from several journals or articles that disclose solid waste management, which are related to dynamic spatial models of solid waste management. The second is a comparative analysis by comparing the results.

Comparative research is a type of descriptive research that seeks to find answers fundamentally about cause and effect, by analyzing the factors that cause the occurrence or emergence of a certain phenomenon. Comparative research is research that is comparative. This research was conducted to compare the similarities and differences between two or more facts and the properties of the object under study based on a certain frame of mind.

In a research by A A Rumakat, et al, with the title Development Of A Solid Waste Level Index, five aspects related to Municipal Solid Waste Management (MSWM) were mentioned. These aspects are used as components in the service level index. The following is described in the table detail.

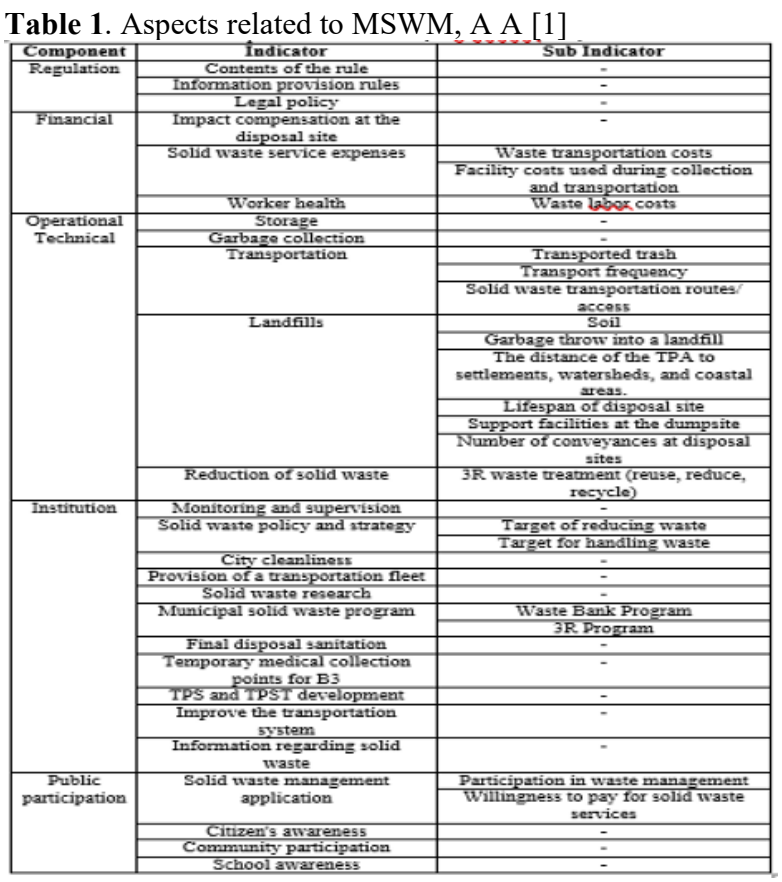


Based on this research, it can be seen that several components of MSWM, regulation, financial, technical operations, institutions and public participation along with indicators and sub indicators. Selection of components refers to the four main literatures, namely Indonesian Government Regulation Number 81 of 2012, Minister of Environment (KLH) Regulation Number 6 of 2014, Integrated Waste Management Scoreboard (IWMS) and Main Performance Index (KPI) for Waste Management.

Also stated in the research of A A Rumakat, et al, that there are two components, namely technical operations and institutions that have a higher value than the others. These two components have more indicators and sub-indicators than the others, so they are more important than the other components. However, in determining the comparative analysis this time the scope is focused only on the technical operational components related to whether the application/ software to be used can answer down to the sub-indicator level. Operational activities are generally related to financial matters, so components, indicators and sub indicators will also be included.

Table 2. Components, indicators and sub indicators for comparative analysis

\begin{tabular}{|c|c|c|}
\hline Komponen & Indikator & Sub Indikator \\
\hline Financial & $\begin{array}{c}\text { Solid waste service } \\
\text { expenses }\end{array}$ & Waste transportation costs \\
\cline { 2 - 3 } & & $\begin{array}{c}\text { Facility costs used during collection and } \\
\text { transportation }\end{array}$ \\
\cline { 2 - 3 } & Worker health & Waste laber costs \\
\hline Operational & Storage & - \\
\cline { 2 - 3 } Technical & Garbage collection & - \\
\cline { 2 - 3 } & Transportation & Transported trash \\
\cline { 2 - 3 } & & Transport frequency \\
\cline { 3 - 3 } & & \\
\cline { 2 - 3 } & & \\
\hline
\end{tabular}

\section{Result}

This research is how to design a solid waste management system using a dynamic systems approach. Dynamic here is related to the development pattern of the waste generation itself. The greater the waste generation, the handling pattern also follows the speed. In addition, the spatial model adds spices from the spatial domain to create a structured, directed pattern, namely the mapping direction of waste handling. The design results are then simulated with possible policy scenarios.

In previous studies, there were two interesting studies to study further. The first research is a research written by Amjad Kallel, et al, entitled Using GIS-Based Tools for the Optimization of Solid Waste Collection and Transport: Case Study of Sfax City, Tunisia. In their research, they presented the results of a spatial model of solid waste management with the help of ArcGIS.
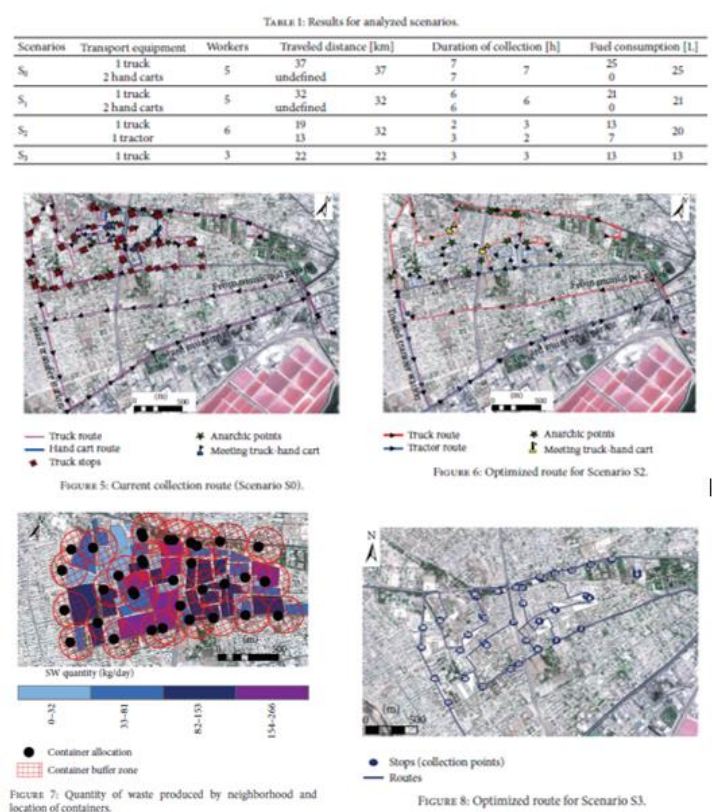

Fig. 1. The results of determining the route of solid waste transportation services using ArcGIS are equipped with a table of results of planning scenarios [2]

The first research shows that ArcGIS can visually display routes/ directions and has the advantage of being able to visually depict existing solid waste patterns, but also patterns planned for the future with measurable details. In addition, it can also display the number of workers, transportation used, collection points, time of collection and consumption of oil/ fuel. The quantity of waste can also be zoned and shows areas with a large amount of waste generation.

The second research is a research written by Octadear Reza Kurniawan, et al, with the title Androidbased Madiun City Landfill Mapping Application with the Assistance of GIS (Geographic Information System). In their research, they presented the results of a spatial model of solid waste management with the help of an Android operating system cellphone.
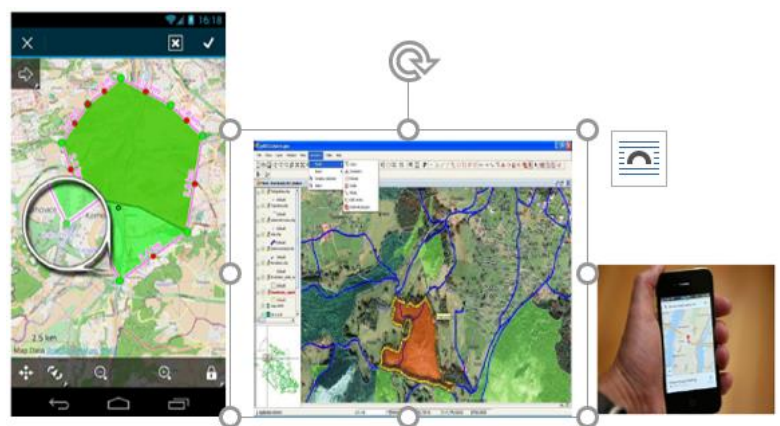

Fig. 2. The results of location determination, map application using PC software, use of GPS in determining coordinates [5]

This research is a study to plan a waste management application using a digital map that already has an example of a Google Map, because there is no further information about the map used. Then the use of GPS on android phones in determining longitude and latitude. Then the data was processed again using PC GIS software which was also not mentioned. 
To get a comparison of these two studies, subindicators were analyzed as a reference for measuring output achievements. The results of a comparative analysis of the two software/ software:

Table 3. Comparative Analysis of Output Data

\begin{tabular}{|c|c|c|c|c|}
\hline \multirow{2}{*}{ Sub Indicator } & \multicolumn{2}{|c|}{ Mapping with ArcGIS } & \multicolumn{2}{|c|}{$\begin{array}{c}\text { Android based mapping } \\
\text { with GPS }\end{array}$} \\
\hline & Output & Data format & Output & Data format \\
\hline $\begin{array}{l}\text { Transported } \\
\text { trash }\end{array}$ & $\begin{array}{l}\text { Map of transport } \\
\text { points }\end{array}$ & ShpoDwg/Jpg & $\begin{array}{l}\text { Map of transport } \\
\text { points }\end{array}$ & $\operatorname{Shp} / \mathrm{Dwg} / \mathrm{Jpg}$ \\
\hline $\begin{array}{l}\text { Transport } \\
\text { frequency }\end{array}$ & $\begin{array}{l}\text { Transport schedule } \\
\text { (daily / weekly/ } \\
\text { annual) }\end{array}$ & $\begin{array}{l}\text { Table } \\
\text { Schedule }\end{array}$ & - & - \\
\hline $\begin{array}{l}\text { Routes / access } \\
\text { to solid waste } \\
\text { transportation }\end{array}$ & $\begin{array}{l}\text { Route/ access maps } \\
\text { transporting solid } \\
\text { waste (from and to) }\end{array}$ & Meter & $\begin{array}{c}\text { Route/ access maps } \\
\text { transporting solid } \\
\text { waste (from and to) }\end{array}$ & Meter \\
\hline $\begin{array}{l}\text { The cost of } \\
\text { transporting } \\
\text { waste for } \\
\text { example the } \\
\text { consumption of } \\
\text { dump truck oil }\end{array}$ & $\begin{array}{l}\text { From route/ access } \\
\text { data transportation } \\
\text { of solid waste (the } \\
\text { previous sub } \\
\text { indicator), then the } \\
\text { distance of } \\
\text { transportation can be } \\
\text { determined }\end{array}$ & $\begin{array}{c}\text { Table } \\
\text { freight costs }\end{array}$ & 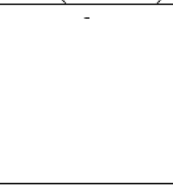 & - \\
\hline $\begin{array}{l}\text { Facility costs } \\
\text { used during } \\
\text { transportation, } \\
\text { for example the } \\
\text { use of dump } \\
\text { trucks and } \\
\text { motorized trash } \\
\text { cans, use of } \\
\text { brooms, use of } \\
\text { trash cans }\end{array}$ & $\begin{array}{c}\text { From the map of } \\
\text { transportation points } \\
\text { (the previous sub } \\
\text { indicator) it can be } \\
\text { seen the number of } \\
\text { bins }\end{array}$ & $\begin{array}{c}\text { Table } \\
\text { number of } \\
\text { facilities, } \\
\text { Facility cost } \\
\text { table }\end{array}$ & - & - \\
\hline $\begin{array}{l}\text { Waste labet } \\
\text { costs }\end{array}$ & $\begin{array}{l}\text { Zoning map of the } \\
\text { number of workers } \\
\text { at the specified } \\
\text { points, as well as } \\
\text { operators of dump } \\
\text { trucks and } \\
\text { motorbike garbage } \\
\text { bins }\end{array}$ & Shp/Dwog/Jpg & $\begin{array}{l}\text { Zoning map of the } \\
\text { number of workers } \\
\text { at the specified } \\
\text { points, as well as } \\
\text { operators of dump } \\
\text { trucks and } \\
\text { motorbike garbage } \\
\text { bins }\end{array}$ & Shp/Dwg/Jpg \\
\hline
\end{tabular}

\section{Discussion}

After a comparative analysis has been carried out, it can be concluded several things, Dynamic Spatial Model can answer some of the proposed sub indicators. ArcGIS is able to accurately visualize several related data. And directly without other software/ applications process data in tabular form. However, there are several shortcomings, human resources who will process the data must be responsive to various possible problems and solutions from the various tools that have been created.

Android-based mapping with the help of GPS is still weak in some ways. Optimization and development are still needed. However, this second study is said to be interesting for the author, due to the ease of use of GPS via cell phones with the Android operating system. In the current millennial era with the use of cellphones, it is not only planners that will be facilitated, but also public participation components can strengthen planning even at the evaluation stage.

Why this research can be important because when making decisions, especially for government planning institutions, an in-depth study of the method to be used is needed, this concerns the effectiveness and efficiency of planning. The results of this study can describe what data outputs that can be produced, although not holistically.

\section{Conclusion}

The dynamic spatial model shows that the ArcGIS simulation results can be used as a solid basis for solid waste management to deal with dynamic changes in the future. Especially for the optimal route freight measurement and several other supporting items. Incorporating planning details on paper with real-world boundaries allows for realistic comparisons, for the application of sustainable environmental planning.

\section{Acknowledgment}

The author would like to thank the Center for Environment and Sustainability Science (CESS) Universitas Padjadjaran and The Greening of Industry Network Conference, for organizing the 2020 CSS..

\section{References}

1. A. A. Rumakat, I. Juwana, S. Ainun, Development of a solid waste service level index, Conference on Sustainability Science 2018, IOP Conf. Series: Earth and Environmental Science, Bandung, Indonesia (2019)

2. A. Kallel, M. M. Serbaji, M. Zairi., Using GISBased Tools for the Optimization of Solid Waste Collection and Transport: Case Study of Sfax City, Tunisia, Hindawi Publishing Corporation, Journal of Engineering, Sfax, Tunisia (2016)

3. E. Damanhuri, T. Padmi, Pengelolaan Sampah Terpadu, ITB Press, Bandung (2016)

4. F. D. K Ching, Arsitektur : Bentuk, Ruang dan Tatanan, Penerbit Erlangga, Jakarta, (2007)

5. O. R. Kurniawan, M. N. Anggraini, P. Utomo, Aplikasi Pemetaan Lokasi TPA Kota Madiun Berbasis Android dengan Bantuan SIG (Sistem Informasi Geografis), Seminar Nasional Sistem Informasi 2019, Malang, Indonesia (2019) 